\title{
Study on Craftsman's Spirit and the Cultivation of Contemporary College Students' Sense of Social Responsibility
}

\author{
Zhifang Sun \\ Beijing Polytechnic College, Beijing, 100042, China
}

Keywords: Craftsman's spirit, Higher vocational college students, Sense of social responsibility.

\begin{abstract}
Students from higher vocational colleges should not only have great skills, but also have a good professional spirit and professional attitude, which just fit the craftsman's spirit. In order to be the most popular talents in the new era,college students must strive to improve their skills and strengthen their sense of social responsibility with the craftsman's spirit. This paper puts forward the way of cultivating higher vocational college students' social responsibility, aiming at providing theoretical and realistic basis for higher vocational education in future.
\end{abstract}

\section{Introduction}

Premier Li Keqiang first introduced the concept of the "craftsman's spirit" during his government work report during the 2016 annual sessions of the nation's legislators. This spirit requires skilled talents to fulfill their tasks with enthusiasm, concentration, precision and persistence. In our country, higher vocational colleges are mainly the cradle of skilled talents. Therefore, it is the social and historical responsibility of higher vocational colleges to attach great importance to and cultivate the craftsman's spirit. Vocational colleges are obliged to teach students the spirit, improve their vocational skills and enhance their sense of social responsibility, providing the Chinese manufacturing and creation with intellectual and technical support.

\section{The connotation of the craftsman's spirit}

The craftsman's spirit was included in Yaowenjiaozi as one of the top ten catchphrases in 2016 and has been a popular phrase in recent years. As a matter of fact, there is history of craftsman's spirit in China. As the old saying goes, "Each and every profession produces its top experts", even in so-called low-level industries, many practitioners treat their own work with determination, patience and the desire to achieve perfection. With high standards and great efforts, they are able to make the best of one simple task. Many industries have their own industry jingles, and the nature of these jingles is the craftsman's spirit. For example, there is a jingle as "arms for three years and legs for five, but a mouth for twenty years" in the comic industry, which means great efforts on the mouth of comic actors; as for the chef industry, the jingle goes like this, "no food is too exquisite and no cooking is too careful". That is, the chef should try his best in each procedure during the cooking process; in the field of handicraft arts there is a jingle, "Don't do porcelain tasks without a diamond drill". In spite of great technical difficulty, handicraft requires focus and patience. Among these industries that people looked down upon in ancient times, there were strict industry requirements of their own, called "regulations".

In this new era, no occupation has a distinction between high and low and each industry is highly regarded. Yet it is still necessary to believe in the craftsman's spirit. In the context of reform and innovation, the rapid development of modern information technology has created a large number of craftsmen bearing both traditional and modern craftsman's spirit, such as IT men, High-speed rail 
men, space men and so on. It is their dedication, perseverance, pioneering and innovative efforts that has made the achievements and glory in China today, which is respected all over the world.

Therefore, the author believes that the craftsman's spirit refers to the professional virtue and the pursuit of excellence of all laborers. It includes not only love, dedication, diligence and professionalism, but also the pioneering spirit and the courage to innovate, as well as the pursuit of perfect life. The essence of the craftsman's spirit is the excellence, which is embodied both in the spiritual level and in the skill level, uniting the two and digging in the process of production, management, operation and sales. Therefore, today's craftsman's spirit means a lot more and gets more significant.

\section{Influence of the Craftsman's Spirit on the Sense of Social Responsibility of Higher Vocational College Students}

Higher vocational colleges are set up to cultivate skilled talents in the new era. Different from ordinary colleges and universities, the curriculum setting tends to be more practical than theoretical. In the past few decades, many people have formed the bias that only students with low scores will enter vocational institutions to get training to learn skills, whereas students with high scores aims at undergraduate colleges. Nevertheless, many foreign vocational schools have graduates with great professional skills and dedication to their work, known as the craftsman's spirit. Just the opposite of that in our country, the status of these vocational schools is no lower than famous universities. With the increasing emphasis on the craftsman's spirit, higher vocational colleges must reassure their educational purpose, avoiding the same merging behaviors in the past few years with a large number of secondary schools, colleges and universities, resulting in the lack of high-quality skilled personnel.

Cultivating the craftsman's spirit benefits for the improvement of college students' sense of social responsibility. Despite the education of knowledge and skills, higher vocational colleges should also attach importance to the cultivation of the craftsman's spirit and sense of social responsibility. With deep feelings towards the people, a persistent attitude towards the work and a high sense of responsibility to the society, students get to work with the craftsman's spirit. Students are encouraged to improve their comprehensive quality in the stage of higher vocational education, so that they can contribute to the development of the society, achieve their life value in their career after graduation. Meanwhile they can enhance their individual social value and continuously improve their sense of social responsibility.

The promotion of social responsibility and the realization of self-worth is a two-way process. That is, individuals can promote the development of the society and so can the society. The society can give people a corresponding feedback both spiritually and materially, which provides positive motivation for higher vocational college students, inspiring them to make progress.

\section{Ways to Improve the Sense of Social Responsibility of Vocational College Students through the Cultivation of the Craftsman's Spirit}

\section{Strengthening Ideological and Moral Education}

At present, with the deepening of the education reform in China, the guiding ideology of higher vocational education has gradually changed from the "employment-oriented" type in the past, to the "Connotation construction-oriented" type, focusing on not only the professional knowledge education, but also the ideological and moral education. The improvement of students' sense of social responsibility relies on school's ideal, faith and patriotism education, etc., offering correct values, moral values and social views. In this way, students believe in their social responsibility. Eventually, it will be their highest goal to achieve self-worth by completing tasks assigned by the times. Schools should also emphasize patriotism education in the ideological and political courses. For instance, the education of traditional Chinese virtues, traditional culture, history, socialist values and social development will enhance students' patriotic sentiment, so that students can be deeply concerned 
about the society and the people, and learn knowledge and skills with the craftsman's spirit, in order to be moral, technical young people with a sense of ownership and responsibility.

\section{Creating a Good Atmosphere}

Schools should build a platform to learn the craftsman's spirit to cultivate students' sense of social responsibility. Schools can create a series of theme activities about the craftsman's spirit. For example, by conducting theme classes, students learn and discuss the craftsman's spirit together. By organizing lectures, students express their understanding of the spirit with passionate speeches. Schools can organize a debate and set a certain theme, such as "which is more important, generalist and specialist", or "those who accomplish big things trip or don't trip over little trifles". The process of the debate will surely deepen students' understanding of the craftsman's spirit and social responsibility. The debate turns out to be a class. A social platform is also needed. For example, schools can organize a visit to excellent local factories before the Labor Day, and ask some technical experts to give students a vivid course. Through stories of their contribution and achievement, students understand the importance of the craftsman's spirit and the sense of social responsibility.

\section{Building a high-level internship platform}

Skilled talents are not trained in the classroom. Vocational schools should actively build an internship platform for students. For example in the very beginning, in addition to theoretical study, students will enter the training room to receive the simulation training, according to the actual production process and standard so that students can bear professionalism in mind and strengthen their professional thinking; through targeted learning, students know about the general learning direction of their future, so as to lay the foundation for more in-depth skill learning. More importantly, schools must build a high-quality internship platform for graduating students, avoiding internships in traditional universities offered by some enterprises targeting cheap labor. So schools must strengthen its audit effort while choosing an internship company--to select qualified enterprises as partners for long-term cooperation. Enterprises should also train graduates in the "master-apprentice" pattern. More specifically, to choose a master with high qualifications, superb skills and noble moral character from the staff, and form a one-to-one training relationship with a student; the master will teach his student about their production management experience, the theoretical knowledge of practical work, superb skills and good professional ethics to students. Students should also pioneer and innovate, grasp the meaning of the craftsman's spirit in the course of practice and enhance the cultivation of social responsibility.

\section{Conclusions}

Higher vocational colleges are the cradle of skilled talents. The cultivation of skilled talents depends on the craftsman's spirit, the hard training of the skills, the persistent exploration of a cause and the concern of the fate of the nation. It is important for higher vocational colleges to combine students' skills with their future career and the development direction of the country. Thoughtful, ethical and skillful graduates are trained and cultivated in various ways to prepare a strong intellectual and technical strength for Chinese innovation and manufacturing.

\section{Acknowledgements}

Project of Beijing Social Science Program (SM201510853001).

\section{References}

[1] Wang Shoubin. Vocational Education should Pay Attention to the Cultivation of the "Craftsman's Spirit", China Education Newspaper, 2016-03-11 (2). 
[2] Lian Hong Yang. Craftsman’ Spirit: the Soul of "China Intelligence Creation" , Guangzhou Daily, 2016-03-06 (A2).

[3] Chen Min. On Ways to Cultivate Vocational College Students' Social Responsibility, Henan Science and Technology: College Forum, 2013,01 (01): 225-226.

[4] Wu Xuefen. Ways to Cultivate Vocational College Students' Social Responsibility, Educational Observation (late), 2013,05 (13): 28-31. 